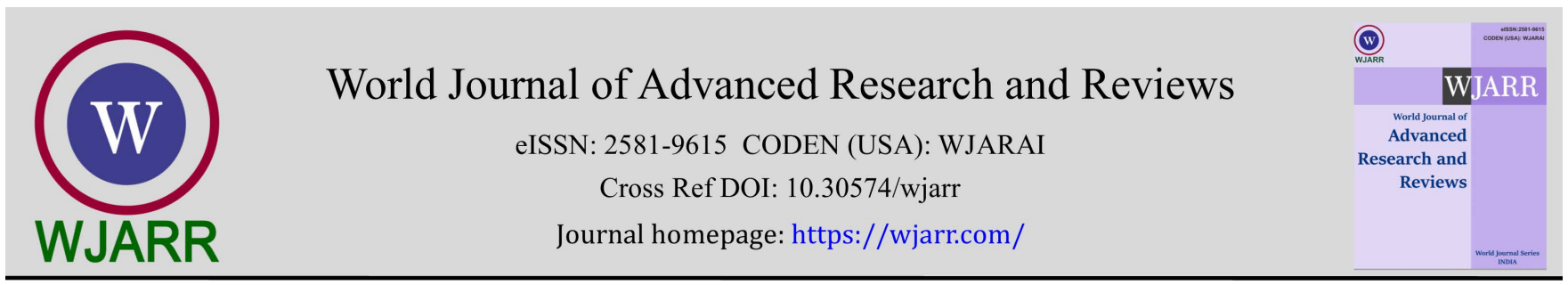

(RESEARCH ARTiClE)

\title{
Assessment of two cichlids stocks with virtual population analysis in Garmat Ali River,
}

\author{
Basrah, Iraq \\ Mohamed Abdul-Razak Mahmood* \\ Department of Fisheries and Marine Resources, College of Agriculture, Basrah University, Iraq.
}

World Journal of Advanced Research and Reviews, 2022, 13(02), 163-172

Publication history: Received on 05 January 2022; revised on 06 February 2022; accepted on 08 February 2022

Article DOI: https://doi.org/10.30574/wjarr.2022.13.2.0134

\begin{abstract}
The study is an attempt to evaluate the population characteristics and virtual population analysis (VPA) of two invasive species (Oreochromis niloticus and Oreochromis aureus) using the FiSAT II software based on the data collected from the Garmat Ali River, Iraq. A total of 4391 individuals (2727 of O. niloticus and 1664 of O. aureus) were measured for lengthfrequency analysis from October 2019 to September 2020. Length-weight relationships were derived, indicating allometric growth for both species. The asymptotic length $(\mathrm{L} \infty)$ and growth rate constant $(\mathrm{K})$ were estimated to be 30.5 $\mathrm{cm}$ and 0.45 for $O$. niloticus and $29.9 \mathrm{~cm}$ and 0.21 for O. aureus. The annual rates of fishing (F) and exploitation (E) for $O$. niloticus were found to be 2.24 and 0.69 , respectively, and for 0 . aureus 0.48 and 0.43 , respectively. The present exploitation rates (E) of both species were below the biological target reference points, E0.1 and Emax, thus expressing a case of under-exploitation of both species. Besides, the result of the virtual population analysis (VPA) revealed that the majority of $O$. niloticus and $O$. aureus individuals were harvested at lengths $20 \mathrm{~cm}$ and $17 \mathrm{~cm}$, respectively. Also, the lengths at first capture $\left(L_{50}\right)$ for both species were considerably higher than their lengths at first maturity $\left(\mathrm{Lm}_{\mathrm{m}}\right)$. Therefore, for management purposes, this study suggests that more yields can be obtained by increasing the fishing activities on these invasive species, such as increasing the number of fishing boats and decreasing the mesh size to decline its abundance in the long term.
\end{abstract}

Keywords: Cichlids; Stock analysis; Virtual population analysis; Garmat Ali River; Iraq

\section{Introduction}

The Nile tilapia, Oreochromis niloticus (Linnaeus, 1758) and the blue tilapia, Oreochromis aureus (Steindachner, 1864) are members of the Cichlidae family. The family is native to Africa and the south-western Middle East and can be found today in other waters around the world inhabiting a variety of fresh and less commonly brackish water habitats, from shallow streams and ponds through the rivers, lakes and estuaries [1]. Fricke et al. [2] stated that this family comprised 251 genera, 2295 available species and 1731 valid species.

Cichlids have been widely introduced, either deliberately for aquaculture or accidentally through the aquarium trade and become the second most important fish in aquaculture after carps, the worldwide production exceeded 5.6 million tons during 2018 [3]. Conversely, Cichlids species are invasive fish to Iraqi waters, and early records show that Coptodon zillii caught from the Euphrates River, middle of Iraq during 2007, later other species, O. aureus and O. niloticus documented in the south of Iraq. Currently, these three species are well established and dominate the fish populations in various Iraqi waters [4-13].

Virtual population analysis (VPA) is a modelling technique commonly used in fisheries science for reconstructing the historical population structure of fish stock using the information on the deaths of individuals in each time step. The

\footnotetext{
${ }^{*}$ Corresponding author: Mohamed Abdul-Razak Mahmood

Department of Fisheries and Marine Resources, College of Agriculture, Basrah University, Iraq.

Copyright $(2022$ Author(s) retain the copyright of this article. This article is published under the terms of the Creative Commons Attribution Liscense 4.0.
} 
time steps are typically annual (though not necessarily) and the deaths are usually partitioned into mortality due to fishing and natural mortality [14]. Virtual population analysis of cichlids has been studied by some investigators in some reservoirs in the world using FiSAT II (FAO-ICLARM Stock Assessment Tools) software such as Ahmed et al. [15] in the Kaptai Reservoir, Bangladesh; Athukorala and Amarasinghe [16] in two reservoirs of the Walawe river basin, Sri Lanka and Amarasinghe et al. [17] in Minneriya, Udawalawe and Victoria Reservoirs, Sri Lanka.

However, there is no study on the virtual population analysis on cichlids species in Iraqi waters. Therefore, the present work covers growth, stock predictions and virtual population analysis of the $O$. niloticus and $O$. aureus populations in the Garmat Ali river, north of Basrah, to provide information for proper management of these cichlids species.

\section{Material and methods}

\subsection{Study area}

The Garmat Ali River is a waterway that connects the East Hammar marsh to the Shatt Al-Arab River, lies in the area between $30^{\circ} 34^{-}$to $30^{\circ} 35^{-} \mathrm{N}$ and $47^{\circ} 43^{-}$to $47^{\circ} 46^{-} \mathrm{E}$ (Fig. 1). The river is affected by the tidal current of the Arabian Gulf through the Shatt Al-Arab River. Its length is about $6 \mathrm{~km}$ with a width of $280 \mathrm{~m}$ and a mean depth of $9 \mathrm{~m}$. Monthly water temperatures for the river ranged from $13.4^{\circ} \mathrm{C}$ to $32.5^{\circ} \mathrm{C}$, with a mean value was $26.3^{\circ} \mathrm{C}$. The shoreline vegetation of the river is typically associated with characteristic emergent macrophytes comprising a majority of Phragmites australis and Typha domingensis, as well as floating species like Ceratophyllum demersum.

\subsection{Fish sampling}

A total of 2727 individuals of 0 . niloticus and 1664 individuals of 0 . aureus were collected monthly from two sites on the river, the first site is located near Al-Najeebia Bridge opposite the site of the Naval Academy and the second site is located at the upper river before its confluence with the East Hammar marsh (Fig. 1) during October 2019 to September 2020 [18]. Fish were caught by drifted gill nets (200-500 m length, with 15x35 mm mesh size), fixed gill nets (100-300 m length, with 15x35 mm, mesh size), cast net ( 9 m diameter, with 15x15 mm mesh size) and electro-fishing by generator engine (providing 300-400V and 10A). After capture, the fish samples were then preserved in a plastic carrier containing enough ice and taken to the laboratory for further analysis.

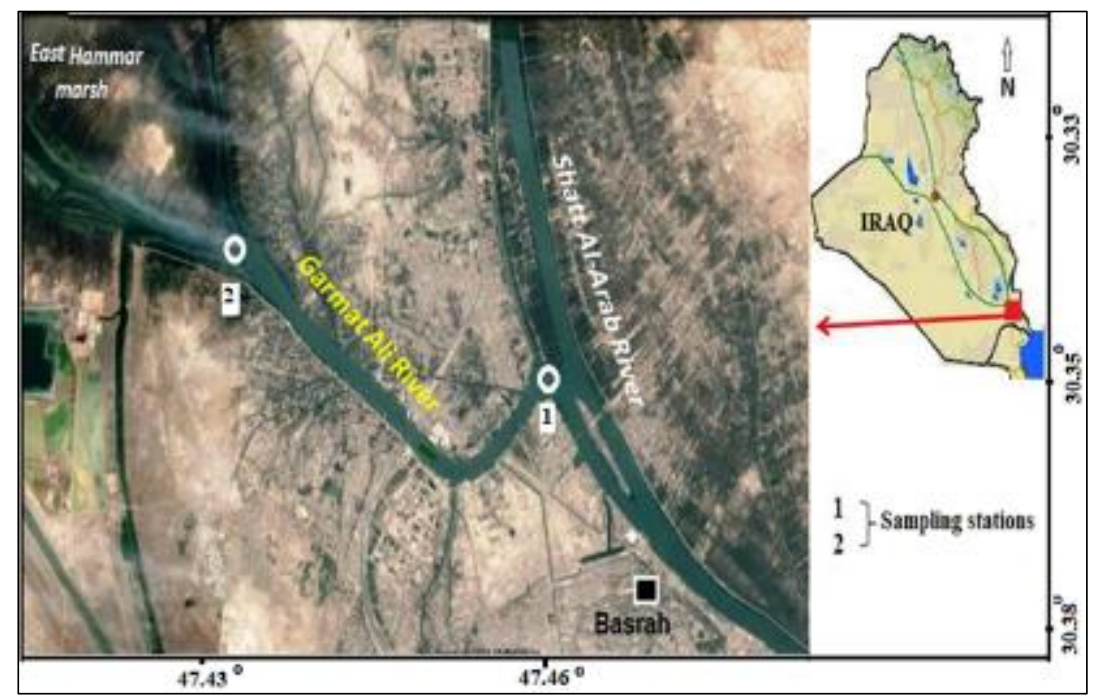

Figure 1 Map of Shatt Al-Arab with locations of study sites

\subsection{Analytical analysis}

At the laboratory, the fish were individually weighed using the electronic weighing balance to the nearest $0.1 \mathrm{~g}$, with the total lengths measured to the nearest $0.1 \mathrm{~cm}$ using the measuring board. The monthly samples of length measurements from the two stations were grouped into 1-cm intervals, sequentially arranged according to a time series of 12 months. The data were analyzed using FiSAT II software (FAO-ICLARM Stock Assessment Tools, ver. 1.2.2) [19]. The total length (L) relationship to the weight $(\mathrm{W})$ for the two species was established using the power equation [20]: $\mathrm{W}=\mathrm{a}^{*} \mathrm{~L}^{\mathrm{b}}, \mathrm{where}$ a the intercept and $b$ is the slope (growth coefficient). Furthermore, the b-value for each species was tested by t-test to verify if it was significantly different from isometric growth [21]. 
The parameters of the von Bertalanffy Growth function (VBGF), asymptotic length (Lo) and growth coefficient (K) were estimated using the ELEFAN-I (Electronic LEngth Frequency ANalysis) routine of the FiSAT II software, which allows the fitted curve through the maximum number of peaks of the length-frequency distribution. With the help of the goodness of fit value $\left(R_{n}\right)$, growth constant $(K)$ and asymptotic length $(L \infty)$ were estimated $[22,23]$.

The instantaneous total annual mortality rate (Z) was estimated using the length-converted catch curve analysis method of Pauly [22] incorporating in FiSAT II program using the input parameters Lo and K, and selecting the best points on the straight line of the right arm of the curve. The natural mortality (M) was estimated using the empirical relationship derived by Pauly [24] where the mean annual water temperature was set at $26.3^{\circ} \mathrm{C}$ :

$\log _{10} \mathrm{M}=-0.0066-0.279 \log _{10} \mathrm{~L} \infty+0.6543 \log _{10} \mathrm{~K}+0.463 \log _{10} \mathrm{~T}$

Thus, the fishing mortality rate (F) was calculated from the relation $F=(Z-M)$.

The relative yield-per-recruit ( $\mathrm{Y}^{\prime} / \mathrm{R}$ ) analysis was carried out using the knife-edge analysis of Beverton and Holt [25] as modified by Pauly and Soriano [26], and the data of $\mathrm{L}_{c} / \mathrm{L} \infty$ and $\mathrm{M} / \mathrm{K}$ values as described in the FiSAT software package to estimate the biological target reference points, E0.1 and Emax [27].

Length-structured virtual population analysis (VPA), which allows the reconstruction of the population from total catch data by length, was carried out by the method of Jones and van Zalinge [28] and incorporated in the FiSAT package to determine the array of (F) for each length class. The input parameters used were L $\infty, \mathrm{K}, \mathrm{M}, \mathrm{F}$ and constants of lengthweight relationship ( $\mathrm{a}$ and $\mathrm{b}$ ) for $O$. niloticus and $O$. aureus were used as inputs to VPA analysis for each species.

The initial step is to estimate the terminal population $\left(\mathrm{N}_{\mathrm{t}}\right)$ given the inputs, from:

$\mathrm{N}_{\mathrm{t}}=\mathrm{C}_{\mathrm{t}} \cdot\left(\mathrm{M}+\mathrm{F}_{\mathrm{t}}\right) / \mathrm{F}_{\mathrm{t}}$

where $\mathrm{C}_{\mathrm{t}}$ is the terminal catch (i.e., the catch taken from the largest length class).

Then, starting from $\mathrm{N}_{\mathrm{t}}$, successive values of $\mathrm{F}$ are estimated, by iteratively solving:

$\mathrm{C}_{\mathrm{i}}=\mathrm{N}_{\mathrm{i}+\Delta \mathrm{t}} \cdot\left(\mathrm{F}_{\mathrm{i}} / \mathrm{Z}_{\mathrm{i}}\right) \cdot\left(\exp \left(\mathrm{Z}_{\mathrm{i}} \cdot \Delta \mathrm{t}_{\mathrm{i}}\right)-1\right)$

where $\Delta t_{i}=\left(t_{i}+1-t_{i}\right)$, and $t_{i}=t_{o}-(1 / K) \cdot \ln \left(1-\left(L_{i} / L_{\infty}\right)\right)$, and where population sizes $\left(N_{i}\right)$ are computed from:

$\mathrm{N}_{\mathrm{i}}=\mathrm{N}_{\mathrm{i}+\Delta \mathrm{t}} \cdot \exp \left(\mathrm{Z}_{\mathrm{i}}\right)$

The last two equations are used alternatively, until the population sizes and fishing mortality for all length groups have been computed [19]. An F-array representing the fishing mortality for each length group, the reconstructed population (in numbers), and the mean stock biomass by length class were made using FiSAT II. The results of the VPA analysis were the biomass (tons), the yield (tons), total and fishing mortality and exploitation ratios.

\section{Results and discussion}

\subsection{Growth}

The length-weight data including 2727 specimens of 0 . niloticus and 1664 specimens of 0 . aureus from the Garmat Ali River during the period from October 2019 to September 2020 were analyzed and their descriptive statistics are presented in Table 1. The length and weight of 0. niloticus was 7.0 to $25.0 \mathrm{~cm}$ and 8.0 to $325.0 \mathrm{~g}$, respectively, while the length of 0 . aureus ranged between 7.5 and $26.3 \mathrm{~cm}$ and their weight varied between 6.0 to $356.0 \mathrm{~g}$. The t-test revealed that the regression slopes (b) in the length-weight relationships for both species were significantly different from value $3(\mathrm{t}=9.02, \mathrm{P}<0.05$ for 0 . niloticus and $\mathrm{t}=4.97, \mathrm{P}<0.05$ for 0 . aureus indicated positive allometric growth for both species.

The outputs from the ELEFAN I and length-converted catch curve routines in FiSAT II software for $O$. niloticus and $O$. aureus in the studied river are summarized in Table 2. The growth curves of both species superimposed over the restructured length-frequency distributions through the ELEFAN I routine are presented in Figure 2. The obtained growth parameters were $\mathrm{L} \infty=34.65 \mathrm{~cm}$ and $\mathrm{K}=0.83$ for 0 . niloticus, and for 0 . aureus were $\mathrm{L} \infty=19.43 \mathrm{~cm}$ and $\mathrm{K}=1.4$ (Table 2). 
Table 1 The ranges for length and weight of $O$. niloticus and O. aureus in the Garmat Ali river.

\begin{tabular}{|c|c|c|c|c|c|c|c|c|}
\hline \multirow{2}{*}{ Species } & \multirow{2}{*}{$\mathbf{N}$} & \multirow{2}{*}{$\begin{array}{l}\text { Length } \\
\text { range }(\mathrm{cm})\end{array}$} & \multirow{2}{*}{$\begin{array}{l}\text { Mean length } \\
( \pm \text { SD) }\end{array}$} & \multirow{2}{*}{$\begin{array}{l}\text { Weight } \\
\text { range (g) }\end{array}$} & \multirow{2}{*}{$\begin{array}{l}\text { Mean weight } \\
( \pm \text { SD) }\end{array}$} & \multicolumn{3}{|c|}{$\begin{array}{l}\text { Length-weight } \\
\text { relationship }\end{array}$} \\
\hline & & & & & & $\mathrm{a}$ & $\mathrm{b}$ & $r^{2}$ \\
\hline O. niloticus & 2727 & $7.0-25.0$ & $15.9( \pm 3.2)$ & $8-325$ & $76.9( \pm 43.1)$ & 0.012 & 3.109 & 0.969 \\
\hline O. aureus & 1664 & $7.5-26.3$ & $14.0( \pm 3.2)$ & $6-356$ & $57.7( \pm 35.7)$ & 0.015 & 3.075 & 0.963 \\
\hline
\end{tabular}
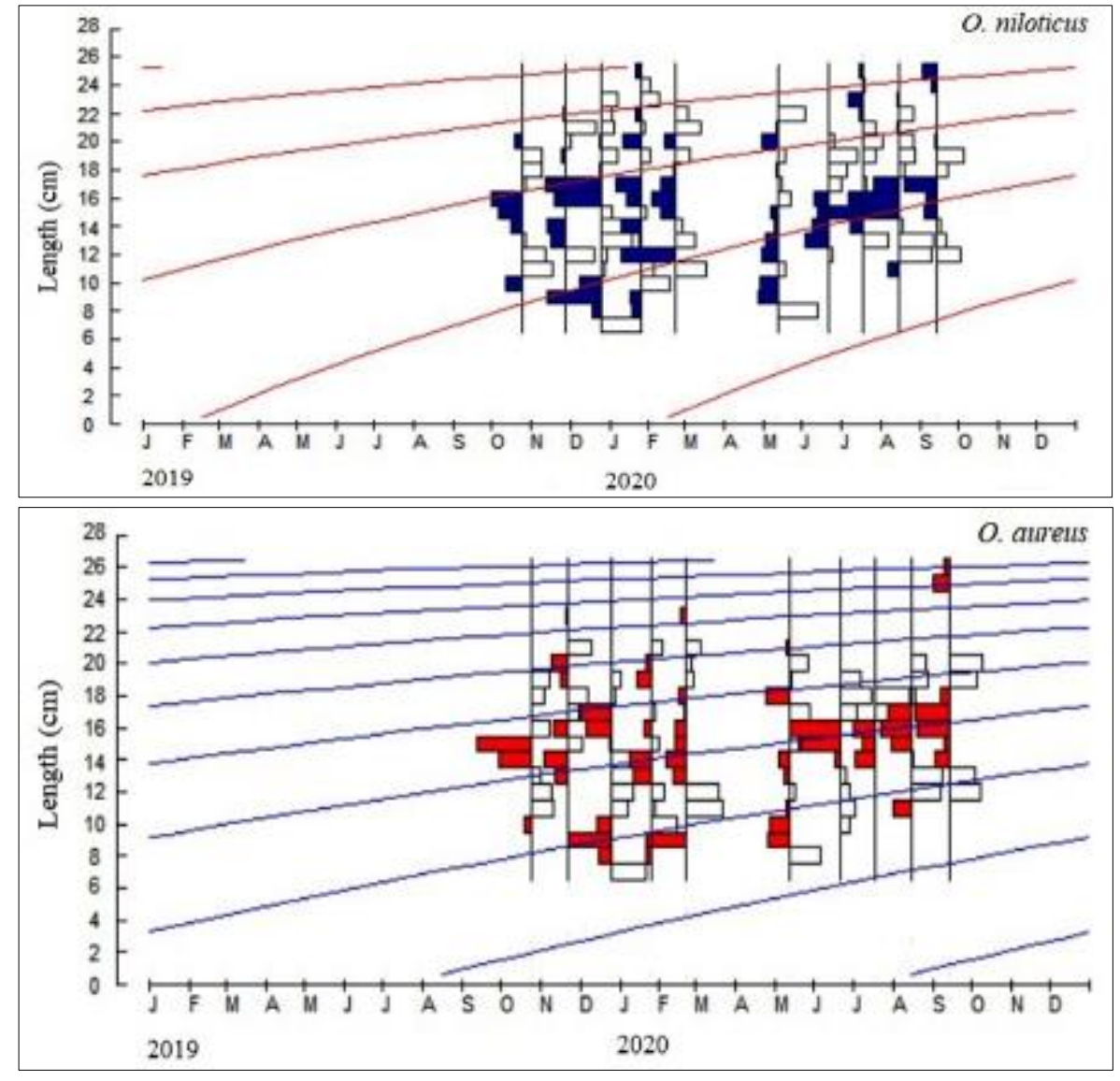

Figure 2 Growth curves of $O$. niloticus and $O$. aureus from the Garmat Ali river, by ELEFAN I superimposed on the length-frequency distribution data.

\subsection{Stock predictions}

The values for the rates of total mortality (Z), natural mortality (M) and fishing mortality (F) for 0 . niloticus were estimated to be 2.24, 1.03 and 2.24, respectively, while for 0 . aureus were $0.48,0.61$ and 0.48 , respectively (Table 2). Moreover, the estimated values of the biological target reference points $\left(\mathrm{E}_{0.1}\right.$ and $\left.\mathrm{E}_{\max }\right)$ for 0 . niloticus were 0.707 and 0.824 , respectively, and for 0 . aureus were 0.706 and 0.877 , respectively. The present exploitation rates (E) are lower than the biological target reference points for both species.

Table 2 Estimates of parameters of growth, mortality and exploitation of $O$. niloticus and $O$. aureus in the studied river.

\begin{tabular}{|l|c|c|}
\hline \multicolumn{1}{|c|}{ Population parameters } & o. niloticus & O. aureus \\
\hline Asymptotic length $(\mathrm{L} \infty, \mathrm{cm})$ & 30.5 & 29.9 \\
\hline Growth coefficient $(\mathrm{K})$ & 0.45 & 0.21 \\
\hline The goodness of fit $\left(\mathrm{R}_{\mathrm{n}}\right)$ & 0.225 & 0.204 \\
\hline
\end{tabular}




\begin{tabular}{|l|c|c|}
\hline Total mortality rate $(\mathrm{Z})$ & 3.26 & 1.09 \\
\hline Natural mortality rate $(\mathrm{M})$ & 1.03 & 0.61 \\
\hline Fishing mortality rate $(\mathrm{F})$ & 2.24 & 0.48 \\
\hline Present exploitation rate (Epresent) & 0.69 & 0.43 \\
\hline Biological target reference point $\left(\mathrm{E}_{0.1}\right)$ & 0.707 & 0.706 \\
\hline Biological target reference point $\left(\mathrm{E}_{\max }\right)$ & 0.824 & 0.877 \\
\hline
\end{tabular}

\subsection{Virtual population analysis}

Table 3 demonstrates the results of the virtual population analysis (VPA) of 0 . niloticus and 0 . aureus. It is clear from the table that the catches of both species occurred from size $7 \mathrm{~cm}$ and peaked at $16 \mathrm{~cm}$. The recruitments of both species into the fishery were estimated at 8188.3 and 5180.0, respectively, then both populations decreased with the increased length classes.

The length groups from $16-22 \mathrm{~cm}$ of 0 . niloticus were more exploited in the fishery, whereas 0 . aureus was $16-19 \mathrm{~cm}$. However, the length group $20 \mathrm{~cm}$ of $O$. niloticus was more vulnerable to fishing (2.595/y), whereas for 0 . aureus was 17

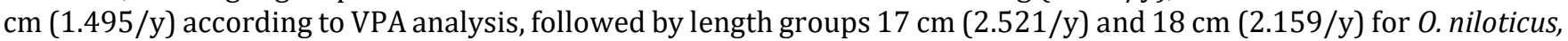
and for 0 . aureus were $16 \mathrm{~cm} \mathrm{(1.400/y)} \mathrm{and} 18 \mathrm{~cm}(1.353 / \mathrm{y})$. The average value of fishing mortality of 0 . niloticus was $1.189 / \mathrm{y}$ that was lower than the value estimated by catch-curve $(2.24 / \mathrm{y})$, whereas for 0 . aureus was 0.533 , and this was slightly high than that estimated by catch-curve $(0.48 / y)$ for the species.

The maximum steady-state biomass of $O$. niloticus happened in length groups $14-15 \mathrm{~cm}(0.02$ ton), whereas 0 . aureus occurred in length groups $12-15 \mathrm{~cm}$ (0.02 ton).

Figure 3 explains the results of the virtual population analysis (VPA) of $O$. niloticus and $O$. aureus in the present study about the natural losses, survivability and fishing mortality. The natural losses and survivability of the fish populations decreased with an increase in length and fishing mortality for both species. Also, it can be seen that the fishing mortality values of both species were not consistent. The highest values of fishing mortality were 2.595 for 0 . niloticus at length $20 \mathrm{~cm}$ and 1.495 for 0 . aureus at length $17 \mathrm{~cm}$, after which there was a gradual decline in fishing mortality values for both species.

\section{Discussion}

Jennings et al. [29] stated that the assessment of fish population is essential to meet one of the main objectives of fishery science, that of maximizing yield to fisheries while safeguarding the long-term viability of populations and ecosystem. In the present study, both tilapia species showed positive allometric growth ( $b>3)$, i.e. this type of growth indicates that the fish becomes relatively stouter or deeper-bodied as it increases in length [30]. This pattern was reported for 0 . niloticus by Mortuza and Al-Misned [31], Kembenya et al. [32], Shalloof and El-Far [33], Cuadrado et al. [34], Negaud [13], and Mohamed and Al-Wan [35] from various water bodies in the world. However, some authors reported negative allometric growth for this species in other waters, such as Novaes and Carvalho [36], Hassan and El-Kasheif [37], Khalifa [38], Teame et al. [39], and Enawgaw and Lemma [40]. Mehanna [41] stated that the growth of O. aureus in Wadi ElRaiyan Lakes, Egypt was also positive allometric growth. Conversely, other studies found to be negative allometric as reported in the Infiernillo Reservoir, Mexico [42], in the Rosetta branch of the Nile River, Egypt [43], in the Aguamilpa Reservoir, Mexico [44], and the Nozha Hydrodrome, Egypt [45]. The difference in growth patterns is affected by several factors, including differences in geographical location, season, sex, stage of fish maturity, food availability, stomach fullness, health, stress and sampling methodology [21, 46, 34, 47].

The difference in the growth of the same species in different geographic locations is caused by several factors, including differences in habitat, environmental conditions, availability of food, metabolic activity, reproductive activity, the genetic constitution of the individual, sizes of fish, fishing pressure and sampling method [23, 52-53].

Virtual population analysis (VPA) is virtual in the sense that the population size is not observed or measured directly but is inferred or back-calculated to have been a certain size in the past to support the observed fish catches and an assumed death rate owing to non-fishery related causes [54]. The rates of fishing mortality (F) and the exploitation (E) 
for $O$. niloticus were higher than that observed for $O$. aureus in this study, and $\mathrm{E}$ of $O$. niloticus passed the optimum exploitation, which tends to be over-exploited according to Gulland [55] suggestion, the optimum exploitation rate is 0.5. The exploitation (E) of $O$. niloticus was close to that obtained of the species by Njiru et al. [56] from Lake Victoria, Kenyan (E= 0.68), and were higher than that observed for this species in other waters, such as Ahmed et al. [15], ElKasheif et al. [49], Yongo and Outa [50] and Shija et al. [51]. On the other hand, the value of the exploitation rate (E) of O. aureus was close to that reported for the species from Lake Victoria, Kenyan by Mahmoud et al. [45], and was lower than those recorded for the species in some waters such as 0.85 in the Wadi El-Raiyan Lakes, Egypt [41], 0.61 in the Rosetta branch of the Nile River, Egypt [43] and 0.57 in Shatt Al-Arab River, Iraq [7].

Table 3 The outputs from the virtual population analysis of $O$. niloticus and $O$. aureus

\begin{tabular}{|c|c|c|c|c|c|c|c|c|}
\hline \multirow{2}{*}{$\begin{array}{l}\text { Length } \\
\text { class } \\
(\mathrm{cm})\end{array}$} & \multicolumn{2}{|c|}{ Catch (numbers) } & \multicolumn{2}{|c|}{ Population (N) } & \multicolumn{2}{|c|}{ Fishing mortality (F) } & \multicolumn{2}{|c|}{ Biomass (tons) } \\
\hline & o. niloticus & o. aureus & o. niloticus & o. aureus & O. niloticus & o. aureus & O. niloticus & O. aureus \\
\hline 7 & 4 & 1 & 8188.3 & 5180.0 & 0.005 & 0.001 & 0 & 0.01 \\
\hline 8 & 105 & 74 & 7422.9 & 4654.6 & 0.151 & 0.093 & 0.01 & 0.01 \\
\hline 9 & 213 & 144 & 6603.6 & 4093.1 & 0.334 & 0.198 & 0.01 & 0.01 \\
\hline 10 & 178 & 120 & 5733.3 & 3505.6 & 0.307 & 0.184 & 0.01 & 0.01 \\
\hline 11 & 110 & 75 & 4957.9 & 2987.6 & 0.208 & 0.128 & 0.01 & 0.01 \\
\hline 12 & 156 & 60 & 4303.8 & 2554.9 & 0.326 & 0.114 & 0.01 & 0.02 \\
\hline 13 & 168 & 127 & 3655.1 & 2172.8 & 0.395 & 0.274 & 0.01 & 0.02 \\
\hline 14 & 264 & 223 & 3048.5 & 1762.2 & 0.720 & 0.582 & 0.02 & 0.02 \\
\hline 15 & 363 & 242 & 2406.6 & 1305.1 & 1.228 & 0.833 & 0.02 & 0.02 \\
\hline 16 & 410 & 271 & 1739.1 & 885.6 & 1.904 & 1.400 & 0.01 & 0.01 \\
\hline 17 & 349 & 169 & 1107.3 & 496.4 & 2.521 & 1.495 & 0.01 & 0.01 \\
\hline 18 & 181 & 86 & 615.7 & 258.3 & 2.159 & 1.353 & 0.01 & 0.01 \\
\hline 19 & 89 & 40 & 348.4 & 133.4 & 1.694 & 1.099 & 0.01 & 0 \\
\hline 20 & 79 & 18 & 205.2 & 71.2 & 2.595 & 0.824 & 0 & 0 \\
\hline 21 & 26 & 6 & 94.9 & 39.9 & 1.554 & 0.418 & 0 & 0 \\
\hline 22 & 19 & 3 & 51.7 & 25.1 & 2.036 & 0.294 & 0 & 0 \\
\hline 23 & 6 & 2 & 23.0 & 15.9 & 1.193 & 0.278 & 0 & 0 \\
\hline 24 & 3 & 0 & 11.9 & 9.5 & 1.023 & 0.000 & 0 & 0 \\
\hline 25 & 4 & 2 & 5.8 & 6.2 & 2.240 & 0.621 & 0 & 0 \\
\hline 26 & & 1 & & 2.3 & & 0.479 & & 0 \\
\hline Mean & & & & & & 0.533 & & \\
\hline
\end{tabular}

The present exploitation rates (E) of both species in the present study were lower than the biological target reference points $\left(E_{0.1}\right.$ and $\left.E_{\max }\right)$, which indicates that the stocks are underexploited in the study river. Moreover, the result of the virtual population analysis (VPA) revealed that the majority of $O$. niloticus and $O$. aureus individuals were harvested at lengths $20 \mathrm{~cm}$ and $17 \mathrm{~cm}$, respectively. Also, the estimated values for the length at first capture (L50) of $O$. niloticus and O. aureus in the same river (14.9 and $13.9 \mathrm{~cm}$, respectively) $[57,18]$ were greater than the lengths at first maturity $(\mathrm{Lm})$ of 0 . aureus, $6.6-9.2 \mathrm{~cm}$ and 0 . niloticus, $7.0-8.0 \mathrm{~cm}[58,35]$. The occurrence of such a situation suggests that individuals of the species get the chance to join the stock before becoming vulnerable to capture by the available fishing gear. These would enable more females to participate in reproductive activity and allow the young recruits to grow and reproduce to ensure resource availability and sustainability [59].

Simoes Vitule et al. [60] indicated that invasive freshwater species are often the culprits driving biodiversity loss, either directly through biotic interactions or indirectly by affecting the availability of essential resources, facilitating the spread of infectious disease, or through hybridization with native taxa. King [61] stated that the overall purpose of fisheries science is to provide decision-makers with advice on the relative merits of alternative management, and this advice may include predictions of the reaction of a stock and fishers to varying levels of fishing effort and, 
conventionally, include an estimate of the level of fishing effort required to obtain the maximum weight or yield that may be taken from stock on a sustainable basis. Since both species are exotic to the Iraqi waters, conservation measures to protect these species, such as the temporary prohibition of fishing, prohibition of fishing gear, controls of fish size caught and control of fishing effort, are not recommended for these waters. However, the impacts of cichlids introduced on native fish and their habitats were well documented [19]. Further, the cichlids are less desired as food by Iraqi people compared to exotic and indigenous cyprinids. For management purposes, more yields could be obtained by increasing the fishing activities on these species.

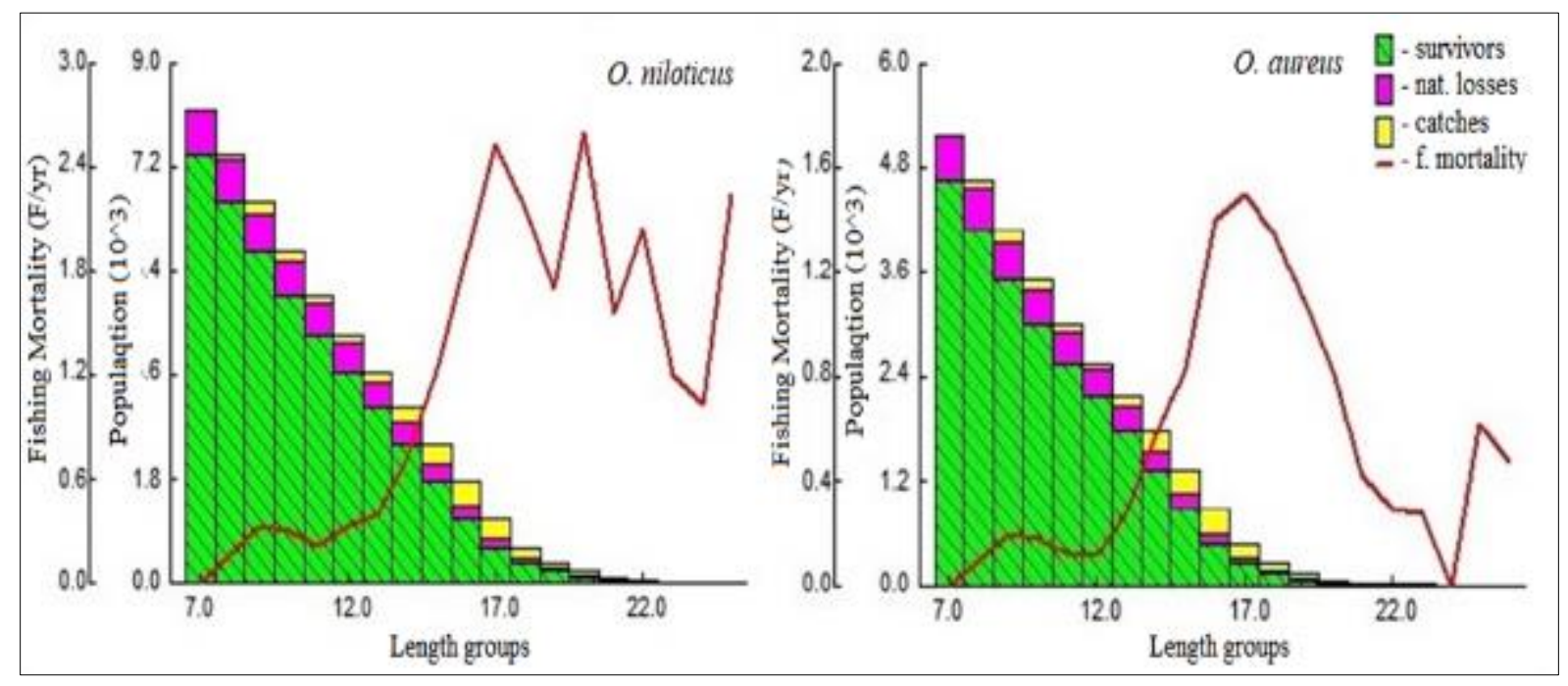

Figure 3 Length-structured virtual population analysis of $O$. niloticus and $O$. aureus

The analysis of growth parameters revealed that the asymptote length of $O$. niloticus (L $\infty=30.5 \mathrm{~cm}$ ) was slightly longer than that of $O$. aureus $(\mathrm{L} \infty=29.9 \mathrm{~cm})$. The growth of $O$. niloticus in the present study was better than that documented for the species $(\mathrm{L} \infty=25.7 \mathrm{~cm})$ by El-Bokhty and El-Far [48] in the River Nile, Aswan, Egypt, while was lower than those reported by other authors [15, 49-51]. Also, the asymptotic length (Lo) for 0 . aureus in this study was better than those recorded for the species in some waters such as $27.2 \mathrm{~cm}$ in the Wadi El-Raiyan Lakes, Egypt [41], $26.4 \mathrm{~cm}$ in the Rosetta branch of the Nile River, Egypt [43] and $27.8 \mathrm{~cm}$ in Shatt Al-Arab River, Iraq [7], whereas lower than the values reported by Messina et al. [44] in Aguamilpa Reservoir, Mexico and Mahmoud et al. [45] in Nozha Hydrodrome, Egypt.

\section{Conclusion}

The study concludes that more yields could be obtained by a reasonable decrease in the size of the first capture and increasing the fishing activities on these invasive species, such as increasing the number of fishing boats and decreasing the mesh size to decline its abundance in the long term.

\section{Compliance with ethical standards}

\section{Acknowledgments}

The author would like to acknowledge the staff of the Department of Fisheries and Marine Resources, College of Agriculture, the University of Basrah for their support of the research.

\section{Disclosure of conflict of interest}

There is no conflict of interest to be declared. 


\section{References}

[1] Uneke BI. Condition Factor of Tilapia Species in Ebonyi River, Southeastern Nigeria. International Journal of Biological Sciences and Applications. 2015; 2(4): 33-36.

[2] Fricke R, Eschmeyer WN, Fong JD. Eschmeyer's Catalog of Fishes. Species by family/subfamily. 2022.

[3] FAO. The State of World Fisheries and Aquaculture 2020. Sustainability in action. Rome. 2020.

[4] Mohamed ARM, Hussein SA, Lazem LF. Spatiotemporal variability of fish assemblage in the Shatt Al-Arab River, Iraq. Basrah Journal of Agricultural Sciences. 2013; 26(1): 43-59.

[5] Shakir HF, Wahab NK. Structure of Fish Community For South East Al-Tharthar Lake in Salah Alddin Province/Iraq. Tikrit Journal for Agricultural Sciences. 2019; 15(2): 111-124.

[6] Abulheni AKJ, Abbas LM. First record of the Tilapia Oreochromis niloticus (Linnaeus,1758) in Euphrates River at Al-Hindia Barrier, Middle of Iraq. Journal of the University of Kerbala. 2017; 18-21.

[7] Mohamed ARM, Abood AN. Compositional change in fish assemblage structure in the Shatt Al-Arab River, Iraq Asian Journal of Applied Sciences. 2017; 5(5): 944-958.

[8] Mohamed ARM, Al-Jubouri MOA. Fish assemblage structure in Al-Diwaniya River, middle of Iraq. Asian Journal of Natural and Applied Sciences. 2017; 6(4): 10-20.

[9] Mohamed ARM, Younis KH, Hameed EK. The ecological condition of the Garmat Ali River, Iraq. Global Journal of Biology, Agriculture \& Health Sciences. 2017; 6(3): 13-21.

[10] Abdullah AHJ, Abdullah SA, Al-Robayii OA. Spatial and temporal pattern of sympatric fish assemblage in the AlSweib River South of Iraq. Proceedings of the 3rd Agricultural Scientific Conference 5-6 March 2018. The University of Kerbala. 2018;1-17.

[11] Abdullah SA, Abdullah AHJ, Ouda YW. Diversity and status of fish fauna in the Al-Kahlaa River, in Missan ProvinceIraq, with notes on environmental variables. EurAsian Journal of BioSciences. 2019; 13: 1817-1824.

[12] Mohamed ARM, Hameed EK. Impacts of saltwater intrusion on the fish assemblage in the middle part of Shatt AlArab River, Iraq. Asian Journal of Applied Sciences. 2019; 7(5): 577-586.

[13] Negaud KZ. Some biological aspects of Nile tilapia Oreochromis niloticus L. in AL-Rumaitha district, Al-Muthanna province, southern Iraq. MSc Thesis, University of Al-Muthanna, Iraq. 2019; 83.

[14] Baharti V. Virtual population analysis. In: Gopalakrishnan A, ed. Advanced Methods for Fish Stock Assessment and Fisheries Management. Central Marine Fisheries Research Institute, Kochi, India. 2017; 232-237.

[15] Ahmed KKU, Amin SMN, Haldar GC, Dewan S. Population dynamics and stock assessment of Oreochromis niloticus (Linnaeus) in the Kaptai Reservoir, Bangladesh. Indian J. Fish. 2003; 50(1): 47-52.

[16] Athukorala DA, Amarasinghe US. Population dynamics of commercially important fish species in two reservoirs of the Walawe river basin, Sri Lanka. Asian Fisheries Science. 2010; 23(1): 71-90.

[17] Amarasinghe US, Prabath RP, Jayasinghe K, Moreau J. Length-based stock assessment of Oreochromis mossambicus and Oreochromis niloticus (Actinopterygii: Perciformes: Cichlidae) in multi-mesh gillnet fisheries in reservoirs of Sri Lanka. Acta Ichthyologica Et Piscatoria. 2017; 47(3): 265-277.

[18] Mohamed ARM, Salman AN. Population dynamics and management of invasive blue tilapia (Oreochromis aureus) in Garmat Ali River, Basrah, Iraq. Asian Journal of Fisheries and Aquatic Research. 2020; 10(2): 44-54.

[19] Gayanilo FCJr, Sparre P, Pauly D. FAO-ICLARM Stock Assessment Tools II (FiSAT II). Revised version. User's guide. FAO Comp. Info. Ser. (Fisheries). 2005; 8: 1-168.

[20] Le Cren ED. The length-weight relationship and seasonal cycle in gonad weight and condition in the perch (Perca fluviatilis). J. Anim. Ecol. 1951; 20: 201-219.

[21] Ricker WE. Computation and interpretation of biological statistics of fish populations. Bull. Fish. Res. Bd. Canada. 1975; 191: 1-382.

[22] Pauly D. Some simple methods for assessment of tropical fish stocks. FAO Fish. Tech. Pap. 1983; $234: 52$.

[23] Sparre P, Venema SC. Introduction to tropical fish stock assessment. Part 1. Manual. FAO fisheries technical paper. No. 306. 1, Rev. 2. FAO, Rome, Italy. 1998; 407. 
[24] Pauly D. On the interrelationships between natural mortality, growth parameters and mean environmental temperature in 175 fish stocks. J. Cons. CIEM. 1980; 39(3): 175-192.

[25] Beverton RJH, Holt SJ. Manual of methods for fish stock assessment. Part II. Fish. Biol. Tech. Pap. 1966; 38: 10-67.

[26] Pauly D, Soriano ML. Some practical extensions to Beverton and Holt's relative yield-per-recruit model. In: Maclean JL, Dizon LB, Hosillo LV, eds. The First Asian Fisheries Forum. 1986; 491-496.

[27] Cadima EL. Fish stock assessment manual. FAO Fisheries Technical Paper. No. 393. Rome, FA0. 2003 ; 161.

[28] Jones R, van Zalinge NP. Estimations of mortality rate and population size for shrimp in Kuwait waters. Kuwait Bull. Mar. Sci. 1981; 2: 273-288.

[29] Jenning S, Kasier M, Reynold J. Marine Fisheries Ecology. Blackwell Science, Oxford. 2000; 391.

[30] Riedel R, Caskey LM, Hurlbert SH. Length-weight relations and growth rates of dominant fishes of the Salton Sea: implications for predation by fish-eating birds. Lake and Reservoir Management. 2007; 23: 528-535.

[31] Mortuza MG, Al-Misned FA. Length-weight Relationships, condition factor and sex-ratio of Nile Tilapia, Oreochromis niloticus in Wadi Hanifah, Riyadh, Saudi Arabia. World Journal of Zoology. 2013; 8(1): $106-109$.

[32] Kembenya EM, Ogellob EO, Githukiac CM, Aerad CN, Omondie R, Mungutif JM. Seasonal changes of length-weight relationship and condition factor of five fish species in Lake Baringo, Kenya. International Journal of Sciences: Basic and Applied Research. 2014; 14(2): 130-140.

[33] Shalloof KA, El-Far AM. Length-weight relationship and condition factor of some fishes from the River Nile in Egypt with special reference to four tilapia species. Egyptian Journal of Aquatic Biology and Fisheries. 2017; 21(2): 33-46.

[34] Cuadrado JT, Lim DS, Alcontin RMS, Calang JL, Jumawan JC. Species composition and length-weight relationship of twelve fish species in the two lakes of Esperanza, Agusan del Sur, Philippines. FishTaxa. 2019; 4(1): 1-8.

[35] Mohamed ARM, Al-Wan SM. Evaluation of biological characters of the invasive species, Coptodon zillii in the Garmat Ali River, Basrah, Iraq. International Journal of Fisheries and Aquatic Studies. 2020; 8(2): 176-185.

[36] Novaes JLC, Carvalho ED. Reproduction, food dynamics and exploitation level of Oreochromis niloticus (Perciformes: Cichlidae) from artisanal fisheries in Barra Bonita Reservoir, Brazil. Revista de Biología Tropical. 2012; 60(2): 721-734.

[37] Hassan AA, El-Kasheif MA. Age, growth and mortality of the cichlid fish Oreochromis niloticus (L.) from the River Nile at Beni Suef Governorate, Egypt. Egyptian Journal Aquatic Biology and Fisheries. 2013; 17(4): 1-12.

[38] Khalifa SZ. Ecological and biological of Nile tilapia Oreochromis niloticus and blue tilapia Oreochromis aureus from Tigris River, Southern Baghdad. MSc. Thesis. University of Diyala. 2017.

[39] Teame T, Zebib H, Meresa T. Observations on the biology of Nile tilapia, Oreochromis niloticus L., in Tekeze Reservoir, Northern Ethiopia. International Journal of Fisheries and Aquaculture. 2018; 10(7): 86-94.

[40] Enawgaw Y, Lemma B. Seasonality in the diet composition and ontogenetic dietary shifts of (Oreochromis niloticus L.) (Pisces: Cichlidae) In Lake Tinishu Abaya, Ethiopia. International Journal of Fisheries and Aquatic Research. 2018; 3(1): 49-59.

[41] Mehanna SF. Population dynamics of two Cichlids, Oreochromis aureus and Tilapia zillii from Wadi El-Raiyn, Lakes, Egypt. Agric. Mari. Sci. 2004; 9(1): 9-16.

[42] Jiménez BL. Age-growth models for Tilapia Oreochromis aureus (Perciformes, Cichlidae) of the Infiernillo reservoir, Mexico and reproductive behaviour. Rev. Boil. Trop. 2006; 54(2): 577-588.

[43] Mahmoud MH, Mazrouh MM. Biology and fisheries management of Tilapia species in Rosetta branch of the Nile River, Egypt. Egyptian Journal of Aquatic Research. 2008; 34(3): 272-285.

[44] Messina EP, Varela RT, Abunader JIV, Mendoza AAO, Arce JM. Growth, mortality and reproduction of the blue tilapia Oreochromis aureus (Perciformes: Cichlidae) in the Aguamilpa Reservoir, Mexico. Rev. Biol. Trop. 2010; 58(4): 1577-1586.

[45] Mahmoud MH, Ezzat AA, Ali TE, El Samman A. Fisheries management of cichlid fishes in Nozha Hydrodrome, Alexandria, Egypt. Egyptian Journal of Aquatic Research. 2013; 39(4): 283-289.

[46] Froese R. Cube law, condition factor and weight-length relationships: history, meta-analysis and recommendations. Journal of Applied Ichthyology. 2006; 22(4): 241-253. 
[47] Pachla LA, Hartmann PB, Massaro MV, dos Santos T, Antonetti DA, Reynalte-Tataje DA. The length-weight relationship of four fish species captured in the Ibicuí River, southern Brazil. J Appl. Ichthyol. 2020; 36: 383-385.

[48] El-Bokhty EEB, El-Far AM. Evaluation of Oreochromis niloticus and Tilapia zillii fisheries at Aswan region, River Nile, Egypt. Egypt. J. Aquat. Biol. Fish., 2014; 18(3): 79-89.

[49] El-Kasheif MA, Authman MMN, Al-Ghamdi FA, Ibrahim SA, El-Far AM. Biological Aspects and Fisheries Management of Tilapia Fish Oreochromis niloticus (Linnaeus, 1758) in El-Bahr El-Faraouny Canal, Al- Minufiya Province, Egypt. Journal of Fisheries and Aquatic Science. 2015; 10(6): 405-444.

[50] Yongo E, Outa N. Growth and population parameters of Nile tilapia, Oreochromis niloticus (L.) in the open waters of Lake Victoria, Kenya. Lakes and Reservoirs: Research and Management. 2016; 21: 375-379.

[51] Shija BS, Tesfaye G, Dadebo E. Assessment of Maximum Sustainable Yield and Optimum Fishing Effort for the Nile Tilapia (Oreochromis niloticus L.) in Lake Chamo, Ethiopia. Journal of Agriculture and Environmental Sciences. 2019; 4(2): 69-86.

[52] Wootton RJ. Growth: environmental effects. In: Farrell AP, ed. Encyclopedia of fish physiology: from genome to environment (Elsevier Science Publishing Co. Inc, United States. 2011; 1629-1635.

[53] Panda D, Mohanty SK, Pattnaik AK, Das S, Karna SK. Growth, mortality and stock status of mullets (Mugilidae) in Chilika Lake, India. Lakes \& Reservoirs. 2018; 1-13.

[54] Shepherd J G, Pope JG. Dynamic pool models I: Interpreting the past using Virtual Population Analysis. In P. J. B. Hart PJB, Reynolds JD, eds. Handbook of Fish Biology and Fisheries. Vol. 2. Fisheries. Oxford, UK: Blackwell Science. 2002; 127-136.

[55] Gulland JA. Fish resources of the Ocean. Fishing News Books, Surrey, London, England. $1971 ; 255$.

[56] Njiru M, Getabu A, Jembe T, Ngugi C, Owili M, Knaap, M. Management of the Nile tilapia (Oreochromis niloticus (L.)) fishery in the Kenyan portion of Lake Victoria, in light of changes in its life history and ecology. Lakes \& Reservoirs: Research and Management. 2008; 13: 117-124.

[57] Salman AN, Mohamed ARM. Growth, mortality and yield-per-recruit of invasive Nile tilapia (Oreochromis niloticus) in Garmat Ali River, Basrah, Iraq. Asian Journal of Applied Sciences. 2020; 8(6): 350-360.

[58] Al-Wan SM, Mohamed ARM. Analysis of the biological features of the blue tilapia, Oreochromis aureus in the Garmat Ali River, Basrah, Iraq. Asian Journal of Applied Sciences. 2019; 7(6): 776-787.

[59] Uneke BI, Nwani CD. Reproductive dynamics and virtual population analysis (VPA) of Tilapia zillii (Perciformes: Cichlidae) in a tropical flood river basin. Nigerian Journal of Fisheries. 2013; 10 (1 \& 2): 642-652.

[60] Simoes Vitule JR, Freire CA, Simberloff D. Introduction of non-native freshwater fish can certainly be bad. Fish and Fisheries. 2009; 10: 98-108.

[61] King MM. Fisheries Biology, Assessment and Management. 2nd ed. Blackwell Publishing Ltd. 2007. 